\title{
STSIM: A Stakeholder-Teacher-Student Interactive Model in the College of Computer and Information Sciences at King Saud University
}

\author{
H. I. Mathkour and A. M. Artoli \\ Vice-deanship for Development and Quality \\ College of Computer and Information Sciences \\ King Saud University \\ P. O. Box 51178, Riyadh 11543 \\ Kingdom of Saudi Arabia \\ Emails:\{mathkour; aartoli\} @ ksu.edu.sa
}

\begin{abstract}
The stakeholder, teacher and student relationship in the College of Computer and Information Sciences is explained. A working model aiming at enhancement and monitoring of the output quality and meeting the demands of the stakeholders in the Kingdom of Saudi Arabia is introduced. Being inspired by the university mission and its social responsibility, the college mission is implemented and directed as the key engine in each program and course objectives. A strategic plan for the college probes and control the college output using a real-time monitoring and a swat team engagement. Each program has a five-year action plan which inspires and controls the development of the college output and measures the key performance indicators for the education-research-community service processes. The college programs are involved in highly demanding national and international academic accreditation processes which acquire certain requirements and measure the development of several performance indicators for the academic as well as community service activities. Each course folder contains information on the objectives of the course, its impact on the overall mission of the college and its targeted skills required by key stakeholders. Extensive exposure of the system elements of education and training to the integral culture gifted by the diversity of its staff and students has proven successful.
\end{abstract}

Keywords: stakeholder theory; computer and information science; stakeholder model; King Saud University.

\section{Introduction}

Globalization and digital divide will be responsible for shaping the knowledge economy of nations in the near future. The nature of future socio-economic activities reflects on the policies and philosophy of doing business in general and in education and research as much. This is due to the fact that all processes and factors affecting the development of globalization exploit resources which highly depend on the same parameters determining the global and internal 
digital divide parameters. The process of a nation development is determined by the knowledge contribution to the international community and how conscious this knowledge is produced [1,2]. The process of managing the amount and quality of knowledge produced and optimal delivery of competitive outcomes remains a challenge for the administration of any high education institution which are highly affected by external environments. The global economic reform towards the knowledge based economy will rely on knowledge production, educators as knowledge producers, students as future outcomes and knowledge users, in addition to stakeholders from the closed family up to the governmental layer. The stakeholder-teacher-learner triangle interrelationship is commonly integrated in various models of innovative flavor characteristic of each institution. These models play key factors in the future of the products as well as the consumers. Institutions must also think ahead of the stakeholders to foresee their requirements and satisfy their ambition.

In the gulf region, information technology and telecommunication are the most growing business sectors affecting the socioeconomic and the future of the region. Other businesses have ICT as their backbone and their demands on ICT are growing dramatically. It is predicted that among every three job announcements, one will be of an ICT nature in the kingdom of Saudi Arabia in the coming few years. This has raised an awareness of the policy makers and the academic institutions about the effectiveness and future of ICT disciplines and the stakeholder-institution interrelationships. The benefits stakeholders are currently receiving from the institution may not be enough to satisfy their demands which are necessary for them to survive their businesses.

King Saud University was founded in 1957 as the premier and oldest university in the Kingdom of Saudi Arabia. It is one of the largest and top ranked academic institution in the Middle East, with annual harvest of nearly ten thousand (more than 11\% of KSA alumni in 2012)undergraduate and one thousand graduate (about 14\% of KSA in 2012)students in natural sciences, social sciences, humanities, medicine, engineering and professional studies. The university has well established research units with high productivity and moderate citations and is fully engaged in community service through strong ties with industry, government entities and strategic consultations. In computer science and information, more than 500 alumni are prepared for the business market every year, which is about $10 \%$ of the KSA harvest in ICT alumni at the bachelor level. Based on a recent survey on the alumni and major employers made by the college alumni unit of the College of Computer and Information Sciences (CCIS), more than $70 \%$ of the college alumni are employed in their discipline within one year after their graduation in governmental institutions, 
telecommunication companies and information technology businesses[2]. The college alumni have esteemed reputation and have the largest chance of employment and research as well[2]. This has been achieved through implementation and monitoring of highly ambitious strategic plans at all levels involved in the production process which all feature strengthening the ties among stakeholders and building the future economy. The college administration and faculty members are highly committed to satisfy the increasing and high-frequency changing stakeholders demands.

The aim of this paper is to analyze the interrelationship among stakeholders, knowledge providers and students in a typical computer college at a leading university in the middle east. We report how the college plans and activities are tailor-made to strengthen the stakeholder-teacher-student relationship. A model based on these data and the stakeholder theory is built. The model tries to compromise for better integrity and conscious interest balance [3].

\section{The CCIS College}

Since it was established about 30 years ago, the college of computer and information science has established good ties with its stakeholders including all those listed in table 1. By now, as many as five thousand students have obtained their degrees in computer science, computer engineering, information science, software engineering and information technology. The college vision targets a world-wide excellence and leadership in research and education in computing and informatics. The mission of the college is to advance the frontiers of knowledge and to prepare creative minds in computing disciplines with commitment to serve the community in order to participate in moving towards a knowledge-based economy through developing an environment that stimulates excellence, creativity, and innovation in education and research. The main objectives of the college are to sustain excellence, to ensure creativity and innovation of research, to strengthen the graduate competitiveness, to bolster faculty and staff performance and to expand the college impact on local society. The college is committed to excellence, discovery leadership and teamwork [4].

Lecture rooms and laboratories of the college are equipped with state of the art technology including e-podiums, advanced laboratories of robotic, computer architecture and specialized centers of excellence in information security and computing.

The college has recruited more than 500 faculties of whom $20 \%$ are non-Saudi from diverse academic cultures, all graduated from leading institutions in 
United States, Europe or Japan. The college campus has a distinguished working environment for students, staff and faculty. A survey is conducted every year to measure the satisfiability of all stakeholders to lead enhancement actions.

All college programs are internationally accredited from ABET and are routinely monitored through the ABET procedure. The college ranks in the top 150 computer science faculties worldwide and has active partnership programs with distinguished partners. Of about five thousand informatics alumni graduated in Saudi Arabia in 2012, CCIS has graduated about 11\%[5]. The results of a recent survey conducted on the college alumni by the alumni unit, $73 \%$ of them responded positively to a question on recommending the college for new students[6]. More than $80 \%$ of the surveyed students found a job in their discipline within the first six months after their graduation.

Concerning research, about 134 papers were published in indexed journals. A few medals and inventions are harvested each year[7]. Four research groups are currently active in tackling problems of local and international interest.

\section{KSU- stakeholder model}

With the King Saud University consuming almost 3\% of the government budget, university administration is highly committed to strengthen, monitor and develop its relation with all the university stakeholders for mutual and society benefits. A number of processes are being followed. In figure $1 \mathrm{a}$ simplified model for managing the stakeholder relationships in King Saud University are identified. The model suggests that all stakeholders must first be identified and their mutual relations are to be well defined. Those are shown in figure 2. An institution may have an entity for each a link to a stakeholder is defined and supported. Knowledge providers are the faculty and international research colleagues and inspiring systems from nature. Knowledge providers may be considered as clients to the educational process. The link between and among clients is controllable from within while the relationship with different stakeholders is mutually controlled.

The needs, requirements and interest of stakeholders are identified and analyzed through exploiting the institution resources, including all knowledge providers and mutual resources from the interested stakeholder. An action plan, joint venture or collaborative deals may be agreed upon. The relation would be managed by a commission of members from both sides in addition to some experts of international reputation or from the shelf benchmark information. Certain key performance indicators (KPIs) are to be defined together with 
means of monitoring their progress. The benchmarking process is essential to guarantee worldwide performance. Assessment is important for institution effectiveness and quality assurance. Opportunities and threats are pinpointed using SWOT analysis given the institution and the stakeholder resources as inputs.

\section{Identifying the stakeholders}

Computer engineering and science are the fastest growing disciplines in the gulf region and their outcomes are expected to dominate the future jobs worldwide.

Stakeholder theory was introduced to enable descriptive practice on guiding the structure and operation of corporate institutions [8]. It is useful to apply the stakeholder theory to analyze and determine the institution development, stakeholders satisfaction, their needs and requirements. The management of this relation involves identifying the senior management group, stakeholder entities, interests and importance, and their needs and expectations. The plans are then restructured in accordance $[9,10]$.

In Table 1, a list of various stakeholders with their roles, importance and outcomes is given for the college of computer and information sciences. From this table, we realize that the college is fully supported from the governmental bodies and the university administration. The university has a reasonably high budget as compared to other academic institutions in the region and worldwide. The college receives administrative and financial support through a highly transparent, fully automated and closely linked to the government financial institutions. The university management system encourages accountability and responsibility, which are adopted in the university strategic plan. All activities are managed through limited delegations and close auditing. However, the college performance is slightly affected by the centralized administrative and financial cycles which are now under continuous restructuring in response to the university strategic plan KSU 2030[11].

So, the stakeholders would ask: of almost three percent of the country budget, how much is being spent to ensure development and leadership in ICT? To answer this question, the college of computer science conducts a number of studies to monitor, analyze, evaluate and enhance its operations in education, research and community service.

In more details, CCIS has four vice-deanships with each being responsible for one cornerstone in the development process. Those are: Vice-deanship for academic and educational affairs, vice-deanship for graduate studies, vicedeanship for development and quality in addition to the administrative and logistic support unit. Each unit is responsible for fostering the college 
objectives and enhancing the college outcomes in education, research and community services in an optimal manner. To do that, the college council and the advisory board meet regularly to set policies, share resources and coordinate facilities. The advisory board of the college involves members from industry, influential academic leaders, minsters and reputed alumni. The college strategy and its action plans are raised to the advisory board before they are approved by the University council.

In addition, the university vice-rectors support, monitor and evaluate the college performance quite regularly. In particular, the university Deanship of development and quality works closely with the college vice-deanship for development and quality to assure that the educational environment, the college preparedness and the key performance indicators of the college strategic plan are progressing. All departments in the college respond to the development and quality requirements through assigned committees nominated in the beginning of each academic year.

\section{Accreditation partners}

The college has opted to involve highly credible international accreditation institutions as independent assessors for its progress. In Education, All programs of the college have been accredited by ABET (the Accreditation Board for Engineering and Technology) engineering and computing accreditation commissions since 2010[12]. The accreditation process runs at the course level, with each course folder containing enough information about how stakeholders will benefit from the course as delivered. The college programs are also involved in the National Commission for Academic assessment and accreditation (NCAAA) local accreditation program administered by the Ministry of High Education running in parallel to the international accreditation continuing procedures. The NCAAA accreditation has 11 main parameters starting from the mission, vision and objectives of each program, going through the administrative and academic processes and more important here are student administration and support services (standard 5), financial planning and management (standard 8), employment process (standard 9) and relationship with the community (standard 11)[13]. The College has benefited from the accreditation procedures in meeting the standards of the accrediting organization, documenting the processes and monitoring the development of its own standards through its internal quality management system. However, a huge effort is being spent on satisfying these standards for each program for each course. A directing committee was appointed to guarantee that both staff and administration will not be distracted from their major tasks in education and research. As shown in Table 1, the roles and outcomes of government, ministry, university and accreditation institutions are considered primary. 
Table 1: Stakeholder analysis of King Saud University, college of Computer and information science

\begin{tabular}{|l|l|}
\hline Stakeholder & Role and outcomes \\
\hline Government & $\begin{array}{l}\text { \$3 BN annual financial support to the university, largest university budget } \\
\text { in the kingdom and in the region. }\end{array}$ \\
\hline $\begin{array}{l}\text { Ministry of } \\
\text { High education }\end{array}$ & $\begin{array}{l}\text { Local accreditation, technical and financial support to strategic activities, } \\
\text { coordinated intake? }\end{array}$ \\
\hline University & $\begin{array}{l}\text { Resource management, Development, maintainence and upgrading of } \\
\text { infrastructure for education and research Adminstrative support } \\
\text { Supply. \#\% of research produced; \% of undergraduate alumni; \#\% of } \\
\text { postgraduate students. }\end{array}$ \\
\hline $\begin{array}{l}\text { International } \\
\text { institutions }\end{array}$ & $\begin{array}{l}\text { Monitoring and evaluation of development towards excellence. International } \\
\text { reputation }\end{array}$ \\
\hline Faculties & $\begin{array}{l}\text { 100\% Graduated from best known universities (US and Europe). } \\
\text { Continuous training. Support for research activities, Diversity }\end{array}$ \\
\hline $\begin{array}{l}\text { Senior } \\
\text { management }\end{array}$ & $\begin{array}{l}\text { Strategic plans (KSU 2030 and CCIS 2015 action plan), Monitoring and } \\
\text { evaluation, automation of all administrative, financial and educational } \\
\text { processes. }\end{array}$ \\
\hline Students & $\begin{array}{l}\text { Satisfied, best known to employ, potential participation in international } \\
\text { activities and local community services, patents. }\end{array}$ \\
\hline Support staff & Commitment, support and enhanced working conditions. \\
\hline Competitors & Cooperation, collaboration, knowledge exchange and fair competition. \\
\hline Partners & $\begin{array}{l}\text { Joint ventures, collaborative research projects, involvement in problem } \\
\text { solving, expertise advice, mutual involvment in teaching, research and } \\
\text { community service activities. }\end{array}$ \\
\hline $\begin{array}{l}\text { Local } \\
\text { community }\end{array}$ & $\begin{array}{l}\text { Awareness, optimal resource management, minimal impact on the } \\
\text { environment. }\end{array}$ \\
\hline $\begin{array}{l}\text { National } \\
\text { community } \\
\text { community }\end{array}$ & $\begin{array}{l}\text { Transparency and accountability, models of excellence, Future Welfare for } \\
\text { students and their families } \\
\text { program provides excellent students to conduct cutting edge research in } \\
\text { reckoned universities in US and Europe, enhancement of financial } \\
\text { conditions to more than ?? international staff, 35 citations per paper, Ranked } \\
\text { as } 179 \text { in QS }\end{array}$ \\
\hline
\end{tabular}

Table 2: Teaching and support staff of CCIS at KSU

\begin{tabular}{|l|c|l|l|l|}
\hline & PhD & Non-PhD & Support staff & Sum \\
\hline Males & 113 & 141 & 46 & 300 \\
\hline Females & 34 & 188 & 44 & 266 \\
\hline Total & 147 & 329 & 90 & 566 \\
\hline
\end{tabular}

\section{Faculty}

Table 2 counts and categorizes faculty and staff in the college. All PhD faculties have received their doctorates from top ranked universities in US and Europe. They are involved in all educational, research and administration activities. Students are distributed among faculty members for advisory and close follow-ups. 
Concerning research, college staff productivity approaches one ISI-indexed paper per faculty. Research focus is on solving problems raised by stakeholders [11,14]. A researcher is rewarded for each published indexed paper. Contract renewal may depend on the teaching staff research activity.

Staff are encouraged and rewarded for submitting innovative projects aiming at enhancement of the educational process or the curriculum. An annual competition is organized for this purpose. On the other hand, external stakeholders may support research projects of up to $\$ 500,000$. Community projects are supported through the college strategic plan and on individual advisory and consultancy services to government private and charity organizations [14].

\section{Students and alumni}

Students are the main stakeholders (customers) of the educational process. If the educational process is highly optimized, the students will spend less effort and time to satisfy the learning goals and attain the required skills for future jobs. The institution should enable seats in response to the recommendations of reliable research on the community needs, requirements and interests. Ideally, a student would know which jobs he or she would get before getting enrolled in an undergraduate course. The institution must provide means of training, which make its alumni highly competitive and most acceptable. Eventually, the institution will be recognized globally based on the quality of its alumni who join academia or industry. If the harvest quality is declining, the institution will not serve the community but rather will damage the enabled resources and affect the local and global market field-related economy.

Relation with old alumni and close communication is a major success parameter for measuring the quality of service and coping with the changing job demands. Universities are proposing life-long training to their alumni as a direct support to their continuous success in the job market. However, it is not easy to establish such relation since it is normally difficult to convince universities about their responsibility toward already graduated students. Life-long training, on-job training and job hunting programs need to be well established and funded mutually by universities and their partners who are employing their alumni. In addition, organizing social alumni activities such as home coming events and pilot projects in community services will make the relation more effective. Institutions would better realize the importance of having relations with their $\mathrm{x}$-alumni more if they are involved in accreditation procedures.

\section{Modeling the stakeholder-teacher-student relationship}

Figure 1 identifies and illustrates proposed links among different stakeholders in an academic institution. In this figure, any connecting line represents a tie 
linked to an institution entity responsible for strengthening relation towards mutual benefits. the major processes and outcomes of the learning activities within an academic institution. For instance, the administration must have well defined plans and ambitious strategy to strengthen the university relationship with its clients, namely, students, faculty and staff for mutual benefits. This operation usually exploits the whole university system if not it is clearly monitored and managed. This may be achieved through decentralization and full automation.

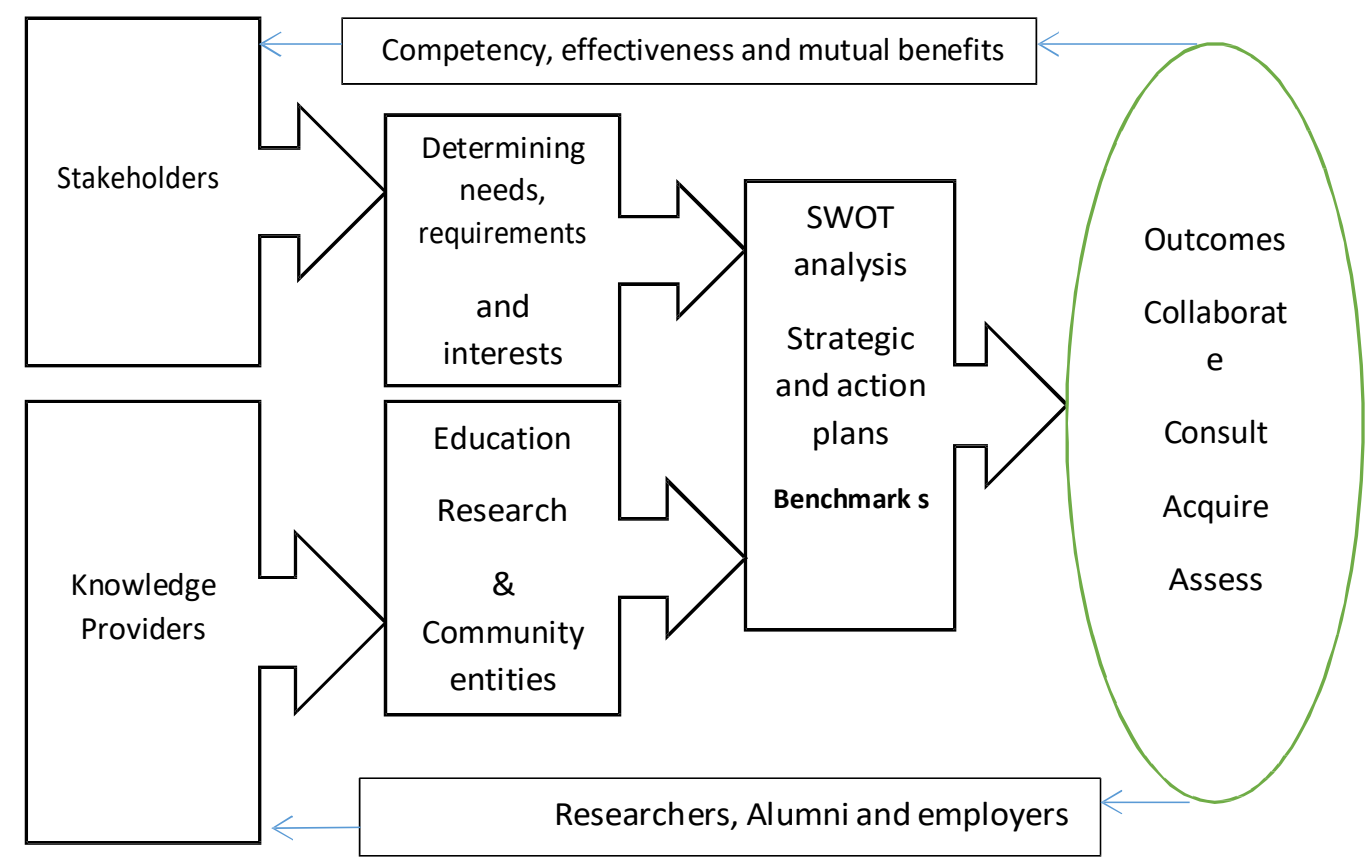

Figure 1: Modeling the stakeholder relationship in academic institutions

\section{Summary}

Being engaged in directing the stakeholder program in the college, this work reflects authors own experience and presents their opinion on how the model works toward continuous strengthening of the stakeholders-teachers-learner interrelationship. We have discussed issues related to effective management of these relations through a working model which has been presented briefly. The mathematical representation for this model is available for a future publication. Stakeholder satisfaction on the educational system and college outcomes was measured using several bi-annual regular automated surveys. The results of these surveys are analyzed and published and recommendations for further enhancement of the stakeholders' involvement and their relation to educators and learners are suggested. 


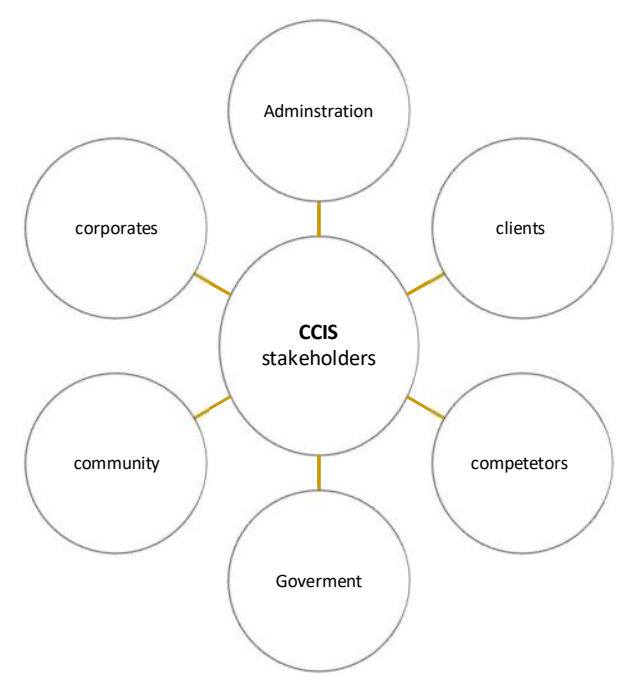

Figure 2: Stakeholders involved in an academic process.

\section{References}

1. I. Mareć, "Stakeholder analysis of higher educational institutions". Interdisciplinary Description of Complex Systems 11(2), 217-226 (2013).

2. T. Donaldson; and P.E. Preston, "The Stakeholder Theory of the Corporation: Concepts, Evidence, and Implications". Academy of Management Review (Academy of Management) 20 (1): 71 (1995).

3. C. Blattberg, "Welfare: Towards the Patriotic Corporation". From Pluralist to Patriotic Politics: Putting Practice First. New York: Oxford University Press. pp. 172-184 (2004).

4. CCIS college strategic plan 2010-2015. Internal report.(2010).

5. High Education Statistics Center, Saudi Ministry of High Education , (2012).

6. CCIS Alumni Unit survey (2013).

7. CCIS book of publications, (2013).

8. T. Donaldson and L. Preston, "The Stakeholder Theory of the Corporation: Concepts, Evidence, and Implications," Academy of Management Review, Vol. 20, pp. 65-91 (1995).

9. B. Jongbloed, J. Enders and C. Salerno, "Higher education and its communities: Interconnections, interdependencies and research agenda". Higher Education, 56, 303-324. (2008).

10. M. Polonsky,. “A stakeholder theory approach to designing environmental marketing Strategy”. The Journal of Business \& Industrial Marketing, 10(3), 29-37. (1995).

11. King Saud University Strategic Plan for 2030. King Saud University (2010).

12. http://www.abet.org as visited on September (2013).

13. The homepage for the Accreditation Board for Engineering and Technology, http://www.abet.org.

14. NCAAA Websitehttp://www.ncaaa.org.sa

15. CCIS annual report (2013). 